\title{
No Calm After the Storm: A Systematic Review of Human Health Following Flood and Storm Disasters
}

\author{
Dell D. Saulnier, Msc; Kim Brolin Ribacke, PhD; Johan von Schreeb, MD, PhD
}

Centre for Research on Healthcare in Disasters, Department of Public Health Sciences, Karolinska Institutet, Stockholm, Sweden

\section{Correspondence: Dell Saulnier, Msc Widerströmska huset, Plan 4 \\ Tomtebodavägen 18a \\ 17177 Stockholm, Sweden \\ E-mail: Dell.saulnier@ki.se}

Conflicts of interest/funding: The authors were funded by the Swedish National Board of Health and Welfare (Stockholm, Sweden) while writing this paper. The funders had no role in the design, data collection, analysis, decision to publish, or writing of the manuscript.

Keywords: cyclonic storms; disaster; floods; health effects; systematic review

\section{Abbreviations:}

ARR: attributable rate ratio

CO: carbon monoxide

ECF: emergency care facility

NCD: noncommunicable disease

$\mathrm{RR}$ : relative risk

Received: September 2, 2016

Accepted: December 18, 2016

Online publication: June 13, 2017

doi:10.1017/S1049023X17006574
Abstract

Introduction: How the burden of disease varies during different phases after floods and after storms is essential in order to guide a medical response, but it has not been well-described. The objective of this review was to elucidate the health problems following flood and storm disasters.

Methods: A literature search of the databases Medline (US National Library of Medicine, National Institutes of Health; Bethesda, Maryland USA); Cinahl (EBSCO Information Services; Ipswich, Massachusetts USA); Global Health (EBSCO Information Services; Ipswich, Massachusetts USA); Web of Science Core Collection (Thomson Reuters; New York, New York USA); Embase (Elsevier; Amsterdam, Netherlands); and PubMed (National Center for Biotechnology Information, National Institutes of Health; Bethesda, Maryland USA) was conducted in June 2015 for English-language research articles on morbidity or mortality and flood or storm disasters. Articles on mental health, interventions, and rescue or health care workers were excluded. Data were extracted from articles that met the eligibility criteria and analyzed by narrative synthesis.

Results: The review included 113 studies. Poisonings, wounds, gastrointestinal infections, and skin or soft tissue infections all increased after storms. Gastrointestinal infections were more frequent after floods. Leptospirosis and diabetes-related complications increased after both. The majority of changes occurred within four weeks of floods or storms.

Conclusion: Health changes differently after floods and after storms. There is a lack of data on the health effects of floods alone, long-term changes in health, and the strength of the association between disasters and health problems. This review highlights areas of consideration for medical response and the need for high-quality, systematic research in this area.

Saulnier DD, Brolin Ribacke K, von Schreeb J. No calm after the storm: a systematic review of human health following flood and storm disasters. Prehosp Disaster Med. 2017;32(5):568-579.

\section{Introduction}

The number of weather-related disasters has increased over the last 20 years. Nearly one-half of the disasters were floods, which killed 157,000 people and affected 2.3 billion. Storms were one-quarter of the disasters but were responsible for a larger proportion of fatalities, causing 220,000 deaths and affecting 660,000 people. ${ }^{1}$ As climate change transforms the frequency and severity of weather events in the coming years, the impact of floods and storms is likely to worsen.

The health care response to a disaster should be guided by the known and expected needs of the affected population. It should be prepared for needs caused by the direct effect of the disaster and for the indirect outcomes of the initial impact. This can be achieved by knowing if and how the health of a population changes after a disaster. Response plans should use the best available evidence to understand the immediate, short-term, and long-term health outcomes after a disaster, and how ordinary health care needs are affected.

Despite the commonality of flood and storm disasters, few reviews cover the quantifiable changes in health that occur afterwards or compare the differences. Previous systematic reviews have combined floods and storms in the analysis, ${ }^{2,3}$ but storms have the additional hazard of strong winds. Other reviews have summarized the impact of flood or storm disasters on mortality and the causes, risk factors, or burden of specific diseases. ${ }^{4-7}$ 
These approaches take a preventative public health perspective and are important for reducing a disaster's health impact.

Floods and storms affect health in various ways. ${ }^{2,3,7}$ Contact with flood waters and high-speed winds during a storm, contact with debris, and evacuation and clean-up activities can cause injury. Floods and storms can destroy residential buildings, leading to displacement, overcrowding, increased exposure to animals and insects, and worsened living conditions. They also can damage infrastructure (such as sewage systems or electrical supply), the agricultural process, and health care facilities. This can indirectly lead to the transmission of infectious diseases, increased physiological stress, exacerbation of existing conditions, malnutrition, and lack of access to preventative and curative health care. Improperly using carbon-based fuels during electrical power outages can result in poisonings. However, in order to guide health care activities afterwards, it is essential to know to what extent the burden of disease varies during different phases after floods and storms.

The aim of this systematic review is to elucidate the human health problems following flood and storm disasters. The review will highlight the health problems and needs over time and the knowledge and evidence gaps discovered during the review.

\section{Report}

A search strategy was developed in collaboration with experienced librarians. A literature search using Medline (US National Library of Medicine, National Institutes of Health; Bethesda, Maryland USA); Cinahl (EBSCO Information Services; Ipswich, Massachusetts USA); Global Health (EBSCO Information Services; Ipswich, Massachusetts USA); Web of Science Core Collection (Thomson Reuters; New York, New York USA); Embase (Elsevier; Amsterdam, Netherlands); and PubMed (National Center for Biotechnology Information, National Institutes of Health; Bethesda, Maryland USA) was conducted in June 2015. The search used keywords for floods, storms, mortality, and morbidity (Supplement 1; available online only). Details of the protocol for the study were registered on the PROSPERO (Centre for Reviews and Dissemination, University of York; York, United Kingdom) systematic review register (ID: CRD42016033554). ${ }^{8}$

The primary inclusion criteria for the search were peerreviewed journal articles on human health written in English. Floods or storms that occurred before 1980 were excluded. No geographical limitations were set. The full eligibility criteria are listed in Table 1.

A disaster was defined using the Centre for Research on the Epidemiology of Disasters' (Brussels, Belgium) International Disaster Database guidelines ${ }^{9}$ as an event that met at least one of the following criteria: 10 or more people reported killed; 100 or more people reported affected; or a declaration of a state of emergency or call for international assistance. Health problems were defined as states related to the physical condition that were harmful or unwelcome and could lead to ill health, morbidity, or mortality. Storm refers to an organized, rotating storm system that originates over water and reaches sustained wind speeds of at least 34 knots. ${ }^{10}$ The generic terms for storms are hurricanes, typhoons, or cyclones. For this review, flood refers to a partial or complete inundation of normally dry land with water that was not the result of a storm.

Initial searches produced 15,447 articles. Articles were independently screened by two authors. Screening titles for eligibility left 914 articles. The remaining abstracts were critically reviewed and 148 studies were read in full; 35 were excluded (Figure 1). All articles

\begin{tabular}{|c|l|}
\hline Criteria for Inclusion & Criteria for Exclusion \\
\hline $\begin{array}{c}\text { A descriptive or analytic } \\
\text { epidemiologic study. }\end{array}$ & $\begin{array}{l}\text { An intervention or methodology } \\
\text { study. }\end{array}$ \\
\hline $\begin{array}{c}\text { Outcome a clearly defined and } \\
\text { measurable health problem. }\end{array}$ & $\begin{array}{c}\text { Outcome a mental or } \\
\text { psychosocial health problem. }\end{array}$ \\
\hline $\begin{array}{c}\text { The flood or storm met the } \\
\text { definition of a disaster. }\end{array}$ & $\begin{array}{c}\text { A study population of only rescue } \\
\text { workers or health care } \\
\text { providers. }\end{array}$ \\
\hline $\begin{array}{c}\text { The disaster was a result of a } \\
\text { meteorological } \\
\text { phenomenon. }\end{array}$ & $\begin{array}{c}\text { Outcome a risk factor for health } \\
\text { problems. }\end{array}$ \\
\hline \multicolumn{2}{|c|}{ Saulnier $\odot 2017$ Prehospital and Disaster Medicine } \\
\hline
\end{tabular}

Table 1. Eligibility Criteria for the Review

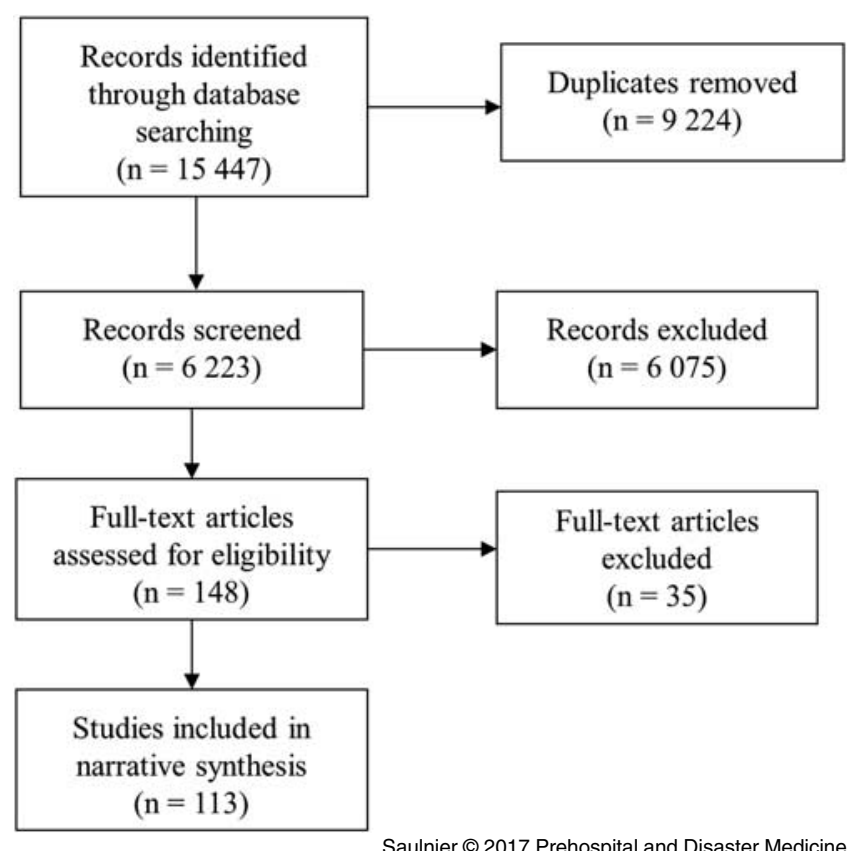

Figure 1. Review Process for the Articles Produced from the Initial Search.

were organized in an EndNote X7.7 library, version 17.5.0.9325 (Thomson Reuters; New York, New York USA). Data were extracted by a trained assistant into a Microsoft Excel spreadsheet, version 15.0.4841 (Microsoft Corporation; Redmond, Washington USA) created by the first author. The extracted data were doublechecked for accuracy and completeness by the first author. Three authors of four studies were contacted by email to provide information that was not available in the published material.

Health problems were sorted into five groups: (1) injuries and poisonings; (2) infectious and parasitic diseases; (3) noncommunicable diseases (NCDs) and chronic illnesses; (4) contact with health services; and (5) other. Groupings were based on the International Classification of Diseases and Related Health Problems $10^{\text {th }}$ Revision (ICD-10) ${ }^{11}$ and the medical input of the last author and other qualified clinicians. For the purpose of this study, all reported 
diarrhea was grouped into the infectious and parasitic diseases category, based on the World Health Organization's (WHO; Geneva, Switzerland) recommended surveillance standards for diarrhea, ${ }^{12}$ unless the article specified another cause.

Due to the large variation in study design and outcomes, data were analyzed by narrative synthesis. Studies that included a control or comparison in their design, and indicated a change in health problems, were selected and presented as key articles for the analysis. Studies were individually assessed for quality. The review followed the PRISMA reporting guidelines. ${ }^{13}$

\section{Results}

The final analysis included 113 studies. Twenty-three articles studied floods, 89 studied storms, and one article included both. The disasters occurred between 1985 and 2014, and the most frequently studied disaster was Hurricane Katrina (2005; Gulf Coast, USA) with 25 articles. There were 77 articles that studied disasters in high-income countries (72 of which were in North America), five were in upper middle-income countries, and 14 each in lower middle-income or low-income countries; three studies included more than one country or the income level was unavailable.

Fifty-two articles were descriptive or correlational studies and described the types and proportions of health problems or causes of mortality seen after a flood or storm. ${ }^{14-66}$ These descriptive results are summarized in Table 2 for health problems and in Table 3 by causes of death. Table 4 lists all health problems reported in the articles. Table 5 gives the number of articles that reported changes for each health problem grouping.

\section{Injuries and Poisonings}

Storms-Poisonings and injuries, especially wounds, were reported as a major source of morbidity after storms. Injuries regularly increased in the period immediately following storms: a study of all emergency care facilities (ECFs) on the island of Hawaii (USA) found an increase in the proportion of injury-related visits within two weeks after a hurricane compared to the five previous years (213 injuries/100,000 people/week increase to 1,461 injuries/100,000 people/week) and an increase in the relative risk (RR) of being injured (RR: 6.85; 95\% confidence interval [CI], 5.98-7.87); ${ }^{67}$ and a study of $113 \mathrm{ECF}$ found a significant increase of $22.3 \%$ in the number of injury-related visits when compared to the same week in the previous year. ${ }^{68}$

Multiple studies reported increases in carbon monoxide (CO) and gasoline poisonings after storms; $\mathrm{CO}$ intoxications presenting at an ECF significantly increased from zero $(0.0 \%)$ to $1.1 \%$ of all ECF visits $(\mathrm{P}=.015)$ in the three days after landfall. ${ }^{69}$ Within two to four weeks after other storms, electronic surveillance identified a significant increase in $\mathrm{CO}$ poisoning, ${ }^{70}$ gasoline exposure was 18 to 283 times higher than the previous four years, ${ }^{71}$ and calls to poison control centers for $\mathrm{CO}$ and gasoline exposure increased from baseline values. $^{72,73}$ A pediatric ECF recorded 13 cases of hydrocarbon and/or bleach poisoning within two weeks after a storm, compared to zero cases in the pre-storm control week and 26 cases for the previous year. ${ }^{74}$

Within one week after storms, the proportion of visits for lacerations and corneal abrasions significantly increased at treatment facilities. ${ }^{69,75,76}$ Within two weeks, the proportion of visits for open wounds increased. ${ }^{74}$ The risk of contusions (RR: 3.29; 95\% CI, 2.36-4.59) and open wounds (RR: 17.3; 95\% CI,
13.0-23.0) also rose at ECFs in the two weeks following a storm compared to the two weeks prior. ${ }^{67}$ Within three weeks after storms, significant increases at treatment facilities in visits for infected wounds, ${ }^{77}$ lacerations, ${ }^{78}$ and puncture wounds ${ }^{78}$ were all reported. No studies reported significant changes in wounds more than one month after landfall.

There were less data showing changes in orthopedic and other injuries. One study found a small but significant decrease $(\mathrm{P}<.001)$ in the percentage of orthopedic trauma visits during the two weeks after a storm, ${ }^{75}$ while a second ECF-based study reported an increase in the risk of sprains (RR: 3.02; 95\% CI, 2.28-3.99) and fractures (RR: 3.38; 95\% CI, 2.14-5.32) compared to two weeks before the storm. ${ }^{67}$ Other reported changes included a significant decrease in visits for soft tissue wounds at a pediatric $\mathrm{ECF}^{74}$ and an increase in the risk of burns and head injuries ${ }^{67}$ in the first week after a hurricane, along with an unexpected number of cases of hypothermia within six weeks after a storm. ${ }^{79}$

While animal bites and insect stings are causes of injuries, not outcomes, it should be noted that five studies reported significant increases at treatment facilities in injuries from bites and stings during the first four weeks after storms. ${ }^{76,78-81}$

Floods-No studies measured changes in injuries or poisonings after flooding.

\section{Infectious and Parasitic Diseases}

Storms-Gastrointestinal illness, leptospirosis, and skin or soft tissue infections generally increased after storms, both at the population and health facility levels. Some studies reported changes in respiratory infections, fevers, and other infectious diseases, but the given information remained inconclusive.

Within seven days, significant increases were seen in diarrhea or gastroenteritis in flooded households and in visits to treatment facilities. ${ }^{74,75,82}$ An analysis of national surveillance system data found an increased risk for shigellosis and other infectious diarrhea, peaking at five days post-cyclone (odds ratio [OR]: 3.56; 95\% CI, 2.98-4.25). ${ }^{83}$ Within five weeks of landfall, the proportion of visits to treatment facilities for diarrhea remained significantly higher than pre-storm levels at an $\mathrm{ECF},{ }^{80}$ the RR for visiting an $\mathrm{ECF}$ for diarrhea was elevated (RR: 2.0; 95\% CI, 1.4-2.8) compared to a same week in the previous year, ${ }^{79}$ and a community survey found a slightly higher risk of diarrhea in two of four storm-affected areas (Area 1 OR: 1.6; 95\% CI, 1.52-1.65 and Area 2 OR: 1.3 ; 95\% CI, 1.21-1.32) compared to the previous two years. ${ }^{84}$ In the long-term, atypical and significant increases were seen in the incidence of acute diarrhea and dysentery in the eight months after a storm, ${ }^{85}$ and the average number of cases utilizing health services for intestinal infections doubled in the year after storm landfall $(6.5$ cases/month to 13.1 cases/month; $\mathrm{P}<.01){ }^{86}$ Alternatively, two surveillance system studies and one ECF study found no change in gastrointestinal illnesses in the post-storm period. ${ }^{78,87,88}$ Outbreaks of cholera ${ }^{89}$ and norovirus ${ }^{90}$ were both identified within two weeks, acute watery diarrhea within six weeks, ${ }^{91}$ and cholera again within three months. ${ }^{92}$ The outbreaks all declined within one to four weeks after they began.

Leptospirosis outbreaks were identified within two weeks, ${ }^{87}$ six weeks, ${ }^{55}$ and two months ${ }^{93}$ after storms. A study of patients who presented at treatment facilities with a dengue-negative fever in the first month after a hurricane found a RR of 4.4 (95\% CI, 1.6-12.4) for having leptospirosis. ${ }^{94}$ 


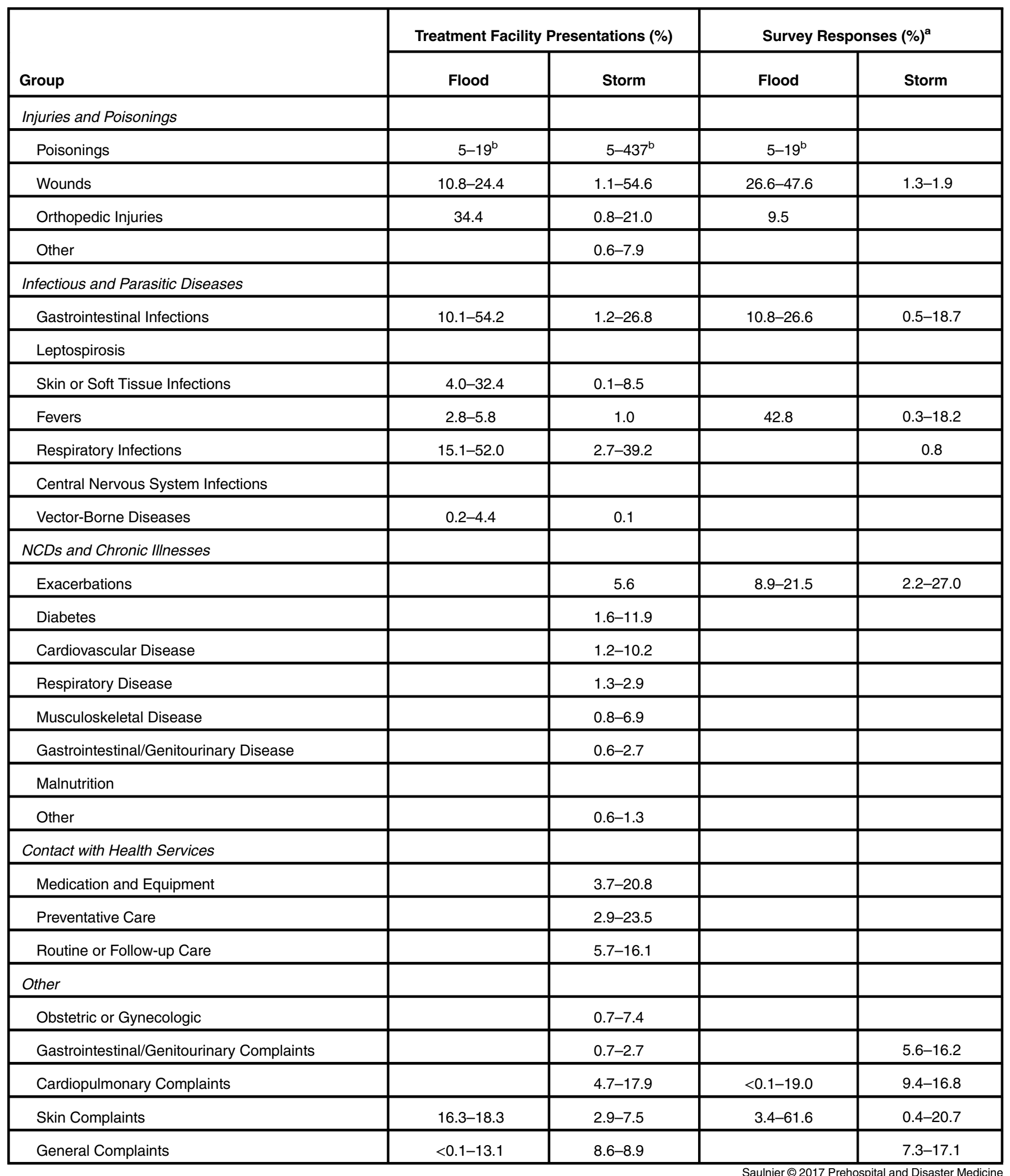

Table 2. Range of Percentages Reported for People Presenting at Treatment Facilities or Responding to Surveys for Specific

Health Problems ${ }^{c}$

Abbreviation: NCD, noncommunicable disease.

${ }^{a}$ Household or community surveys.

${ }^{\mathrm{b}}$ Number of cases.

${ }^{\mathrm{c}}$ No frequency data available for blank cells. 


\begin{tabular}{|c|c|c|}
\hline & \multicolumn{2}{|c|}{ Reported Deaths (\%) } \\
\hline Group & Storm & Flood \\
\hline \multicolumn{3}{|l|}{ Injuries and Poisonings } \\
\hline Drownings & $3.1-69.2$ & $5.8-82.6$ \\
\hline Poisonings & $2.7-17.5$ & 4.3 \\
\hline Burns and Electrocutions & $1.3-11.4$ & 2.4 \\
\hline Trauma & $1.3-100$ & \\
\hline Crush Injuries and Asphyxia & $1.3-14.3$ & 14.4 \\
\hline Violence & $1.0-61.0$ & \\
\hline Other & $1.9-3.0$ & 26.0 \\
\hline \multicolumn{3}{|l|}{ Infectious and Parasitic Diseases } \\
\hline Gastrointestinal Infections & & 27.3 \\
\hline Leptospirosis & $1-15^{\mathrm{a}}$ & $11^{\mathrm{a}}$ \\
\hline Bacterial & $2.6-6.1$ & \\
\hline \multicolumn{3}{|l|}{ NCDs and Chronic Illnesses } \\
\hline Cardiovascular Event & $3.0-57.5$ & \\
\hline Respiratory Event & $2.7-12.1$ & 6.0 \\
\hline Brain Syndromes & $2.6-6.2$ & \\
\hline $\begin{array}{l}\text { Gastrointestinal/Genitourinary } \\
\text { Disease }\end{array}$ & $1.3-3.0$ & \\
\hline Other & 3.0 & \\
\hline \multicolumn{3}{|l|}{ Other } \\
\hline Obstetric & 3.1 & 2.6 \\
\hline Natural Causes & $2.7-34.4$ & 11.0 \\
\hline Neurologic & $3.0-25.0$ & \\
\hline Other & 3.0 & \\
\hline
\end{tabular}

Table 3. Range of Percentages of Deaths, by Cause ${ }^{b}$

Abbreviation: NCD, noncommunicable disease.

${ }^{\text {a }}$ Number of cases.

${ }^{\mathrm{b}}$ No frequency data available for blank cells.

Significant increases in impetigo, conjunctivitis, and cellulitis at treatment facilities were reported in the first two weeks after storms, ${ }^{74,87}$ and the number of lower extremity cellulitis cases receiving treatment at ECFs increased during the first week after landfall (RR: 2.8 ; 95\% CI, 2.0-2.4) compared to the control period. ${ }^{95}$ However, one island-wide surveillance study of all treatment facilities found no increase in visits for skin infections in the week after a cyclone. ${ }^{87}$ Eighteen cases of wound-associated Vibrio illness, linked to a hurricane, also were identified two weeks after landfall. ${ }^{96}$

While one study found a significantly higher incidence rate of acute respiratory illness over the course of a cyclone (pre-storm: 4,041.91 cases/100,000 people; storm period: 7,279.7/100,000; post-storm: $4,661.59 / 100,000)^{85}$ and a second study saw a single, unexpected case of legionellosis in a severely affected area, ${ }^{88}$ two treatment facility-based studies and one surveillance study found no significant increases in respiratory infections. ${ }^{74,75,87}$

Information on other infectious diseases was limited. Visits to treatment facilities for unspecified febrile illness increased in the first week after a storm. ${ }^{79}$ A study of West Nile neuroinvasive disease found an increased incidence (RR: 2.45 ; 95\% CI, 1.77-3.477) in hurricane-affected areas in the three weeks post-storm compared to the three previous years. ${ }^{97}$ Malaria was diagnosed in only $2.5 \%$ and dengue in $1.7 \%$ of patients presenting with fever at a treatment facility more than three months post-storm. ${ }^{98}$ A national surveillance system study reported a slight increase in malaria incidence over the course of a storm but no change in dengue fever. ${ }^{85}$

Floods-Outbreaks of both gastrointestinal illness and leptospirosis occurred after flooding, but there were little data that supported changes in other infectious illnesses.

Three studies identified diarrhea outbreaks: four flood-associated cholera epidemics after three separate floods, with a median onset time of 8.5 days post-flood $;{ }^{99}$ an outbreak of cryptosporidiosis within four weeks; ${ }^{100}$ and 115 disease alerts for acute watery diarrhea and one for blood diarrhea by a surveillance system, indicating the number of diarrhea cases had surpassed a pre-defined threshold over the course of seven weeks from the end of a flood. ${ }^{101}$ However, a time series analysis of diarrheal illness and flood water data from a health and demographic surveillance site found no support for a significant increase in diarrhea, including cholera, non-cholera, and rotavirus, in the three years following major flooding. ${ }^{102}$ Two outbreaks of leptospirosis were confirmed within one month ${ }^{103}$ and more than four weeks ${ }^{104}$ after flooding, while approximately $27 \%$ of children presenting to a treatment facility with acute fever of unknown origin were diagnosed with leptospirosis within the first month after flooding. ${ }^{105}$

Eye infections were seen in a significantly larger proportion of people living in flooded areas within four weeks of a flood compared to those living in non-flooded areas. ${ }^{106}$ One time series study using health and demographic data found a moderate increase in acute respiratory infections (RR: 1.25 ; 95\% CI, 1.06-1.47) within six months after a flood. ${ }^{102}$ Two studies of patients presenting at treatment facilities with acute fever identified malaria in $22 \%$ of the patients, ${ }^{107}$ dengue fever in $29.4 \%$, and scrub typhus in $1.1 \%{ }^{105}$ within two to three months and one month post-flood, respectively, and no change was seen in the proportion of people diagnosed with dengue fever who lived in flooded areas four weeks after a flood. ${ }^{106}$

A surveillance system study of multiple diseases gave seven alerts for suspected measles, one alert for acute hemorrhagic fever syndrome, two alerts for suspected meningitis, and two alerts for suspected poliomyelitis, but no alerts for acute respiratory infection or unexplained fever in the seven weeks after a flood. ${ }^{101}$

\section{Noncommunicable Diseases and Chronic Illnesses}

Storms-The articles in this review suggested an increase in cardiovascular disease and diabetes outcomes in the short- and long-term after storms, and nutritional outcomes manifested in the long-term after some storms.

While one island-wide surveillance study of all treatment facilities found no significant increase in visits for cardiac decompensation in the week after a cyclone, ${ }^{87}$ the proportion of cardiovascular complaints significantly increased at treatment 


\begin{tabular}{|c|c|}
\hline Group and Subgroup & Reported Health Problems \\
\hline \multicolumn{2}{|l|}{ Injuries and Poisonings } \\
\hline Poisonings & $\begin{array}{l}\text { Carbon monoxide, gasoline, bleach, } \\
\text { hydrocarbon. }\end{array}$ \\
\hline Wounds & $\begin{array}{l}\text { Abrasions, contusions, cuts, puncture } \\
\text { wounds, lacerations, corneal } \\
\text { abrasions, infected wounds, open } \\
\text { wounds. }\end{array}$ \\
\hline Orthopedic Injuries & $\begin{array}{l}\text { Fractures, amputations, dislocations, } \\
\text { sprains, strains. }\end{array}$ \\
\hline Other & $\begin{array}{l}\text { Head injuries, soft tissue wounds, } \\
\text { burns, hypothermia. }\end{array}$ \\
\hline \multicolumn{2}{|l|}{$\begin{array}{l}\text { Infectious and Parasitic } \\
\text { Diseases }\end{array}$} \\
\hline $\begin{array}{l}\text { Gastrointestinal } \\
\text { Infections }\end{array}$ & $\begin{array}{l}\text { Cholera, typhoid fever, norovirus, } \\
\text { dysentery (including shigellosis), } \\
\text { gastroenteritis, diarrhea (including } \\
\text { acute watery and bloody), } \\
\text { cryptosporidium infection, } \\
\text { unspecified intestinal infections, } \\
\text { intestinal worms, rotavirus. }\end{array}$ \\
\hline Leptospirosis & Leptospirosis. \\
\hline $\begin{array}{l}\text { Skin or Soft Tissue } \\
\text { Infections }\end{array}$ & $\begin{array}{l}\text { Cellulitis, wound-associated vibrio } \\
\text { illness, measles, impetigo, } \\
\text { conjunctivitis, eye infections. }\end{array}$ \\
\hline Fevers & $\begin{array}{l}\text { Unspecified febrile illness, acute } \\
\text { hemorrhagic fever. }\end{array}$ \\
\hline Respiratory Infections & $\begin{array}{l}\text { Legionellosis, tuberculosis, acute } \\
\text { respiratory infection, upper or lower } \\
\text { respiratory infection, respiratory } \\
\text { syncytial virus. }\end{array}$ \\
\hline $\begin{array}{l}\text { Central Nervous } \\
\text { System Infections }\end{array}$ & $\begin{array}{l}\text { Suspected meningitis, suspected } \\
\text { poliomyelitis, West Nile } \\
\text { neuroinvasive disease. }\end{array}$ \\
\hline Vector-Borne Diseases & $\begin{array}{l}\text { Malaria (including suspected), dengue } \\
\text { fever, scrub typhus. }\end{array}$ \\
\hline \multicolumn{2}{|l|}{$\begin{array}{l}\text { NCDs and Chronic } \\
\text { Illnesses }\end{array}$} \\
\hline Exacerbations & $\begin{array}{l}\text { Exacerbation of a chronic or pre- } \\
\text { existing condition. }\end{array}$ \\
\hline Diabetes & $\begin{array}{l}\text { Diabetes complications, diabetic foot, } \\
\text { diabetes-related amputations, } \\
\text { worsened control of } \mathrm{HbA1c} \text {. }\end{array}$ \\
\hline $\begin{array}{l}\text { Cardiovascular } \\
\text { Disease }\end{array}$ & $\begin{array}{l}\text { Hypertension, other cerebrovascular } \\
\text { disease, cardiovascular event, } \\
\text { myocardial infarction, stroke. }\end{array}$ \\
\hline Respiratory Disease & $\begin{array}{l}\text { Asthma, chronic obstructive } \\
\text { pulmonary disorder, allergic } \\
\text { rhinitis. }\end{array}$ \\
\hline $\begin{array}{l}\text { Musculoskeletal } \\
\text { Disease }\end{array}$ & Chronic joint pain, arthritis. \\
\hline
\end{tabular}

Saulnier $\odot$ Prehospital and Disaster Medicin

Table 4. All Health Problems Reported in the Included Articles, by Subgroup (continued)

\begin{tabular}{|c|c|}
\hline Group and Subgroup & Reported Health Problems \\
\hline $\begin{array}{l}\text { Gastrointestinal/ } \\
\text { Genitourinary Disease }\end{array}$ & $\begin{array}{l}\text { Chronic gastrointestinal condition, } \\
\text { non-diarrheal gastroenteritis, renal } \\
\text { failure, renal-related hospitalizations, } \\
\text { renal disease. }\end{array}$ \\
\hline Malnutrition & $\begin{array}{l}\text { Stunting, underweight, reduced height } \\
\text { gain. }\end{array}$ \\
\hline Other & $\begin{array}{l}\text { Epilepsy, chronic pain syndrome, } \\
\text { hematology/oncology, neural tube } \\
\text { defects, endocrine illness. }\end{array}$ \\
\hline \multicolumn{2}{|l|}{$\begin{array}{l}\text { Contact with Health } \\
\text { Services }\end{array}$} \\
\hline $\begin{array}{l}\text { Medication and } \\
\text { Equipment }\end{array}$ & $\begin{array}{l}\text { Prescriptions, prescription refills, } \\
\text { oxygen. }\end{array}$ \\
\hline Preventative Care & Vaccinations, preventative care. \\
\hline $\begin{array}{l}\text { Routine or Follow-up } \\
\text { Care }\end{array}$ & $\begin{array}{l}\text { Blood pressure or blood glucose } \\
\text { checks, prenatal care, wound care, } \\
\text { hemodialysis. }\end{array}$ \\
\hline \multicolumn{2}{|l|}{ Other } \\
\hline $\begin{array}{l}\text { Obstetric or } \\
\text { Gynecologic }\end{array}$ & Complaints, surgery. \\
\hline $\begin{array}{l}\text { Gastrointestinal/ } \\
\text { Genitourinary } \\
\text { Complaints }\end{array}$ & Abdominal pain, nausea, vomiting. \\
\hline $\begin{array}{l}\text { Cardiopulmonary } \\
\text { Complaints }\end{array}$ & $\begin{array}{l}\text { Respiratory illness, respiratory tract } \\
\text { complaints, cough, shortness of } \\
\text { breath, sore throat, chest pain, nasal } \\
\text { discharge. }\end{array}$ \\
\hline Skin Complaints & Dermatitis, allergic dermatitis, rash. \\
\hline General Complaints & $\begin{array}{l}\text { Headache, dizziness, weakness, } \\
\text { musculoskeletal pain, heat-related } \\
\text { illness, dehydration, jaundice. }\end{array}$ \\
\hline
\end{tabular}

Table 4 (continued). All Health Problems Reported in the Included Articles, by Subgroup

Abbreviation: NCD, noncommunicable disease.

facilities, especially in people 45 years and older, in the two weeks to one month after a hurricane. ${ }^{67,108}$ The incidence of stroke increased by seven percent (attributable rate ratio [ARR]: 1.07; 95\% CI, 1.03-1.11) and myocardial infarction increased by $22 \%$ (ARR: 1.22 ; 95\% CI, 1.16-1.28) in areas highly impacted by a hurricane during the first year afterwards, ${ }^{109}$ and the percentage of admissions to hospitals for acute myocardial infarctions increased significantly within two years. ${ }^{110}$

Evaluations for diabetic foot increased significantly at an ECF within four weeks after a cyclone. ${ }^{77} \mathrm{~A}$ study of diabetic patients between six and 16 months after a hurricane found worsened levels of glycated hemoglobin $(7.7 \%$ to $8.1 \%$; $\mathrm{P}<.01)$ compared to measurements taken in the six months before the storm, with a significant linear trend over time. ${ }^{111}$

The available information on changes in respiratory illness was contradictory. During the first week after a typhoon, a review of insurance claims from typhoon-affected areas found a small increase in patients seeking care for allergic rhinitis (rate ratio: 


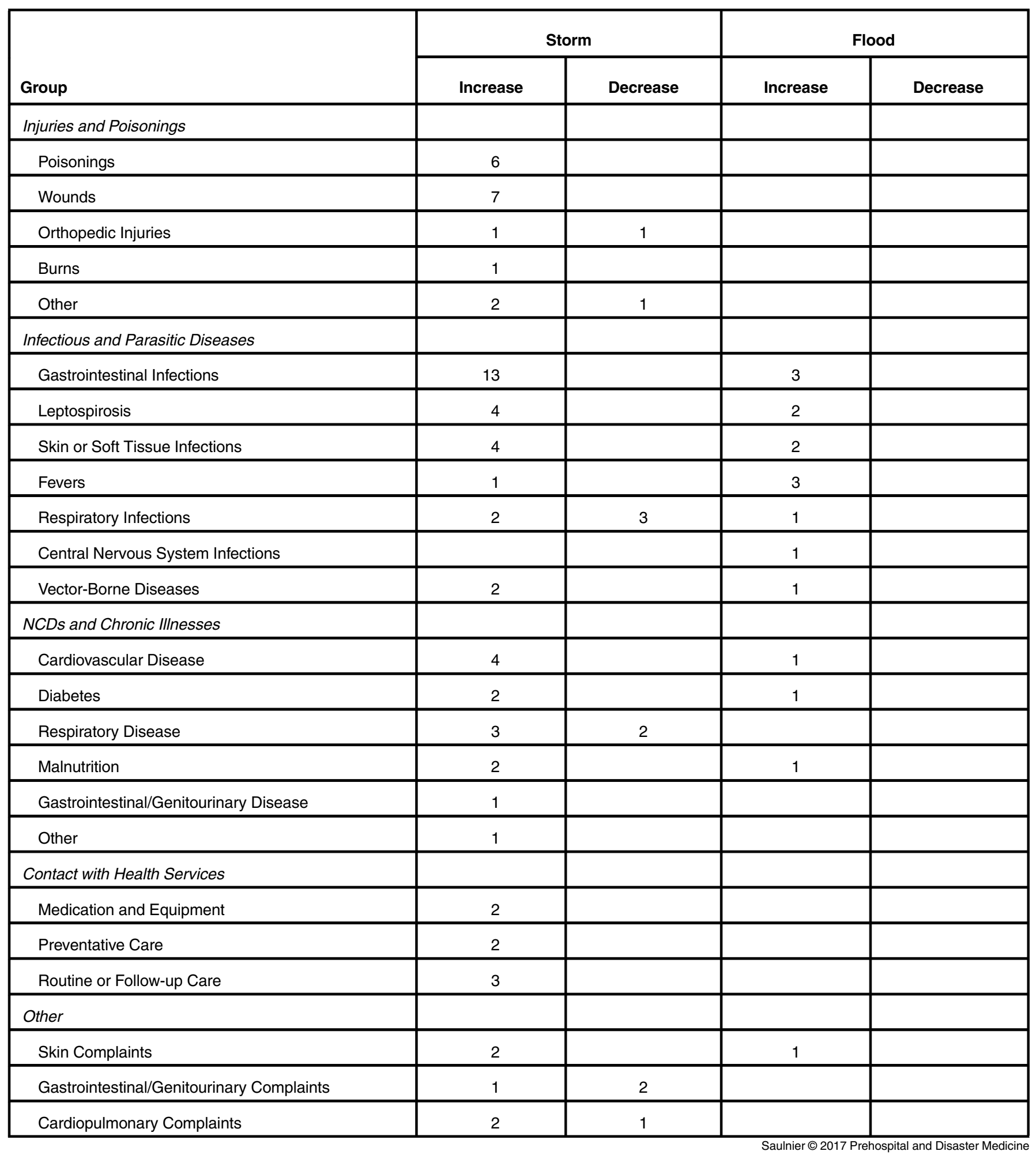

Table 5. Number of Articles Reporting an Increase or Decrease in Health Problems after Floods or Storms Abbreviation: NCD, noncommunicable disease.

1.19; 95\% CI, 1.15-1.23) but a decrease in patients seeking care for asthma (rate ratio: $0.90 ; 95 \% \mathrm{CI}, 0.86-0.93) ;{ }^{112}$ an island-wide treatment facility study found no significant increase in visits for asthma or chronic obstructive pulmonary disease in the week after a cyclone, ${ }^{87}$ although other treatment facilities saw significant increases in visits for asthma two weeks ${ }^{67}$ and one month post-hurricane. ${ }^{79}$ In the one to three months after a hurricane, children with chronic conditions were more likely to have worsened asthma $(16.3 \%$ versus $1.9 \% ; \mathrm{P}<.01)$ than children without chronic conditions. ${ }^{113}$ However, no significant 
relationship was seen between exposure to mold and respiratory allergic response in patients at an allergy clinic in the year after a hurricane. $^{114}$

The remaining studies on NCDs and chronic illnesses saw significantly less height gained in the three months following a hurricane in nutritionally at-risk children under five years old 115 and a significant increase in the stunting/underweight one year after. ${ }^{116} \mathrm{~A}$ spike in renal-related hospital admissions was seen in the month after a hurricane (rate ratio: 2.53 ; 95\% CI, 2.09-3.06) compared to pre-hurricane rates, ${ }^{117}$ and a study of babies born with neural tube defects after a hurricane suggested a link between significantly decreased consumption of folate by mothers and destruction of food crops by a hurricane. ${ }^{118}$

Floods-Information on NCDs after floods was limited, but worsened hypertension and diabetes and long-term malnutrition outcomes were both seen. A household survey four weeks after a flood found a significant proportion of those living in flooded areas whose hypertension worsened since the flood (42.9\% versus $20.3 \% ; \mathrm{P}<.05)^{106}$ and a significant increase in glycated hemoglobin $(7.6 \%$ to $7.9 \%$; $\mathrm{P}=.002)$ was seen among diabetic patients in the first year after exposure to flood compared to the 12 months before the event. ${ }^{119}$ A community survey of children living in villages that had flooded found they were more likely to be stunted and underweight than children from non-flooded villages (adjusted prevalence ratio: 1.86; 95\% CI, 1.05-2.44) at 26 to 36 months post-flood. ${ }^{120}$ One study found no significant difference in musculoskeletal symptoms from wading through flood waters in the three months after a flood. ${ }^{121}$

\section{Contact with Health Services}

Storms-Although articles frequently described an increase in contact with health services after storms, especially within the first week and for health maintenance reasons like prescription refills, data-based results were not often given. Of the reported results, an increase in ECF visits for oxygen, medication refills, dialysis, vaccination, or hemodialysis was seen in two studies in the first three days ${ }^{69}$ and first week after a storm, ${ }^{79}$ and also in "miscellaneous" visits for vaccinations and routine care to a primary health care facility in the week after a hurricane. ${ }^{75}$

Floods-No studies measured changes in contact with health services after flooding.

\section{Other Health Problems}

Storms-Symptoms were frequently reported in the included studies, and no particular trends were seen. Nutritionally at-risk children under five years of age experienced nasal discharge or cough more often in the first one to three months after a hurricane than in the four months preceding the storm, ${ }^{115}$ and a linear increase $(\mathrm{P}<.05)$ was observed for lower and upper respiratory tract symptoms among people exposed to water-damaged homes. ${ }^{122}$ However, the percent of children self-reporting a lower respiratory tract symptom at least once a week decreased in the eight to nine months after a hurricane and no data were found to support a change in upper respiratory tract symptoms or spirometry test values. ${ }^{123}$ Finally, a significant increase in visits for dermatitis at an ECF was seen within one week. ${ }^{79}$ By the second week after storms, significant increases were seen in visits to ECFs for dermatologic conditions ${ }^{74}$ and gastrointestinal complaints ${ }^{80}$ while significant decreases were seen for genitourinary complains and abdominal pain. ${ }^{74} \mathrm{~A}$ similar significant decrease in visits for abdominal pain also was seen within four weeks after a cyclone. ${ }^{77}$

Floods-Only one paper reported a change in other health problems after flooding: there was an increase in the proportion of those living in flooded areas that were diagnosed with dermatitis within four weeks of a flood $(96.5 \%$ versus $57.9 \% ; \mathrm{P}<.05)$ compared to those living in non-flooded areas. ${ }^{106}$

\section{Mortality}

Thirty-two studies reported information on mortality, and fifteen studied it exclusively. Deaths were most often presented as a summary of the cases and causes. Table 6 lists all given causes of death.

Storms-Studies at the population level suggested that there was a minimal change in mortality following storms. Two studies using nation-wide and island-wide mortality surveillance records found no significant increases in mortality in the eight to 12 months after storms for the following causes: heart disease, stroke, cancer, respiratory disease, acute respiratory infections, tuberculosis, injury, diarrheal disease, vaccine-preventable illnesses, meningitis, hepatitis, rabies, malaria, dengue fever, or snake bites. ${ }^{85,124}$ Notably, the island-wide study did find a significant increase in the number of deaths due to diabetes (RR: 2.61 ; 95\% CI, 1.44-4.74). ${ }^{124}$

Local studies found more changes. A study of areas highly impacted by a hurricane found that the 30-day mortality rate for both myocardial infarctions (ARR: 1.31; 95\% CI, 1.22-1.41) and other cardiovascular events (ARR: 1.22; 95\% CI, 1.15-1.30) increased when compared to the five years before the storm; no significant changes in stroke-related mortality were seen. ${ }^{109}$ Over the course of a hurricane season, overall mortality was significantly elevated for two months after the first storm landfall when compared to nonhurricane years; heart, cancer, and accident-related deaths all significantly increased. ${ }^{125} \mathrm{~A}$ study of dialysis-dependent patients in the one-and-a-half years after a hurricane found no significant increase in their mortality risk. ${ }^{126}$

Floods-A study of health and demographic surveillance site data found no support for an increase in all-cause mortality in the three years following a flood. ${ }^{102}$

\section{Discussion}

This review builds on earlier reviews., ${ }^{2,3,127}$ It included new articles, separated floods and storms for the analysis, and assessed the timing of health problems. The results of the review show that health does change differently after floods and after storms. The increases in both acute injuries and some infectious diseases, and the increase in treatment facility visits for NCDs and chronic illnesses seen after both floods and storms, is likely to significantly raise the need for both emergency and routine health care services. There was a remarkably small quantity of data on the health effects of floods alone, suggesting a certain degree of extrapolation for knowledge on floods from storm data.

Although outbreaks of gastrointestinal infections and leptospirosis occurred after floods and storms, no articles reported sustained epidemics of any infectious diseases. This may help in dispelling the myth that epidemics are an inevitable consequence of disasters. ${ }^{128}$ The risk of infectious disease transmission is primarily related to a flood or storm's indirect outcomes, as was seen in 


\begin{tabular}{|c|c|}
\hline Group and Subgroup & Reported Cause \\
\hline \multicolumn{2}{|l|}{ Injuries and Poisonings } \\
\hline Drownings & Flood waters. \\
\hline Poisonings & $\begin{array}{l}\text { Carbon monoxide, ingestion of drug or } \\
\text { substance. }\end{array}$ \\
\hline $\begin{array}{l}\text { Burns and } \\
\text { Electrocutions }\end{array}$ & $\begin{array}{l}\text { Fires, chemicals, smoke inhalation, } \\
\text { power source, lightning strike. }\end{array}$ \\
\hline Trauma & $\begin{array}{l}\text { Motor vehicle accidents, falls, boating } \\
\text { accidents, fallen trees, flying debris, } \\
\text { power tools. }\end{array}$ \\
\hline $\begin{array}{l}\text { Crush Injuries and } \\
\text { Asphyxia }\end{array}$ & Structural collapse, fallen trees. \\
\hline Violence & Gunshot wound, homicide, suicide. \\
\hline Other & $\begin{array}{l}\text { Hypothermia, cerebrovascular } \\
\text { accident, landslide. }\end{array}$ \\
\hline \multicolumn{2}{|l|}{$\begin{array}{l}\text { Infectious and Parasitic } \\
\text { Diseases }\end{array}$} \\
\hline $\begin{array}{l}\text { Gastrointestinal } \\
\text { Infections }\end{array}$ & Diarrhea. \\
\hline Leptospirosis & Leptospirosis. \\
\hline Bacterial & Sepsis. \\
\hline \multicolumn{2}{|l|}{$\begin{array}{l}\text { NCDs and Chronic } \\
\text { Illnesses }\end{array}$} \\
\hline Cardiovascular Event & Myocardial infarction, hypertension. \\
\hline Respiratory Event & $\begin{array}{l}\text { Chronic obstructive pulmonary } \\
\text { disorder, pulmonary conditions, } \\
\text { respiratory failure. }\end{array}$ \\
\hline Brain Syndromes & $\begin{array}{l}\text { Seizures, central nervous system } \\
\text { events. }\end{array}$ \\
\hline $\begin{array}{l}\text { Gastrointestinal/ } \\
\text { Genitourinary Disease }\end{array}$ & Pancreatitis, renal failure. \\
\hline Other & Cirrhosis, cancer, myopathy. \\
\hline \multicolumn{2}{|l|}{ Other } \\
\hline Obstetric & $\begin{array}{l}\text { Obstetric hemorrhage, obstetric } \\
\text { problems. }\end{array}$ \\
\hline Natural Causes & Old age. \\
\hline Neurologic & Intracranial hemorrhage. \\
\hline Other & Shock. \\
\hline
\end{tabular}

Table 6. All Causes of Death Reported in the Included Articles, by Subgroup

Abbreviation: NCD, noncommunicable disease.

this review, where the reported outbreaks were all caused by contaminated water, overcrowded shelter, displacement, and poor sanitation. Public health interventions can be targeted to these outcomes in order to prevent outbreaks.
The increase in treatment for poisonings and wounds seen after storms but not floods is likely the result of strong winds and wind damage during storms. Some wounds were directly sustained during the impact phase of storm (eg, being struck by flying debris); the remaining wounds and the poisonings were indirectly caused in the weeks afterwards (eg, stepping on debris while cleaning up, and $\mathrm{CO}$ poisoning from incorrect use of a gasolinepowered generators). The variation in timing and cause means injuries and poisonings will require different medical needs and this should be accounted for during storm responses.

Floods and storms are indirectly responsible for the exacerbation, acute onset, and worsened management of chronic illnesses and NCDs. Disasters affect both individuals and health service delivery, which in turn affects the management and continuity of care for chronic diseases and NCDs. This is reflected in the results of most of the mortality studies and may be connected to the increases seen in people seeking contact with health services. The care needs of people living with chronic illnesses or NCDs and the expected burden of disease have to be clearly defined for the post-disaster period.

An examination of the available information shows that changes in some infectious diseases and NCDs are well-understood, albeit without conclusive information on the strength of association. But discrepancies were seen on whether certain health problems increased or decreased. Overall, the long-term effects of both floods and storms were not well-covered by the literature and changes have not been well-quantified.

A global overview on health after floods and storms has been presented in this review, but the direct and indirect effects of disasters are tied to the local context. Factors such as climate, income level, infrastructure, and residential security will affect the vulnerability and exposure of the population to different health outcomes, and their long-term medical needs. Since the majority of the studies used to generate the results of this review -77 out of 113 articles - come from studies conducted in high-income settings, the results must be carefully applied to local settings. Health changes also likely differ with the severity of the disaster and the frequency of the population's exposure to floods or storms. Populations that are regularly exposed to one disaster type may be less vulnerable or better adapted to dealing with the disaster's direct and indirect effects than an unexposed population, although these gains can be reduced if the disaster is more severe than expected. An analysis of the contextual factors contributing to the health outcomes seen in this review would be a useful complement to these results.

The lack of conclusive results across the review articles means the usual approach to flood and storm responses may be suboptimal. This was specifically noted in two articles read during the review process, which both described medical teams being over-prepared for injuries and under-prepared for chronic or routine complaints after hurricanes. ${ }^{129,130}$ Combining inconclusive data with limited information on the strength of association can intensify the effect. For instance, the numerous studies on injuries included in this review could be the result of a real association between storms and injuries or the result of an increase in the reporting or surveillance of injuries over the disaster period. If this review is to be used to inform a response, the limitations of the results must be considered.

\section{Limitations}

The variety in study designs, health problems, and quality of the studies led to a number of limitations. The major limitation is the overall quality of the included articles. Nearly one-half of the articles were descriptive and it was not possible to ascertain the 
relationship between the health problems and the disaster: how much illness was exacerbated by the disaster, how much was new, and how much followed the same pattern as before? In addition, a lack of systematic reporting and data collection in the studies meant that health problems lacked definitions, definitions varied between studies, and there was minimal information on the severity of the problems. As a result, the analysis was unable to compare and contrast information on the same health problems between studies or quantify the changes in health.

Second, more than one-half of the studies used health facility data, most frequently from single-site hospital or emergency care records, as a data source. This is likely to skew the results of the review towards the health outcomes of people who had access to health care after the flood or storm, and to an over-representation of health problems that require emergency or specialized care. It is likely that this difference is more pronounced in low-income settings. For instance, in Bangladesh, only $26 \%$ of study participants who developed health problems that were severe enough to require medical care after a flood visited a health care facility. ${ }^{64}$ Applying the results of facility-based studies to the population level, and outside of their original context, should be done prudently. An increase in research at the population level, such as cohort or registry-based studies in disaster-prone settings, would not only generate new, comprehensive data, but would help with the interpretation and application of facility-based results.

Third, articles were often not clear on the length of time between the disaster and the onset or acquisition of a health problem. The results have therefore been presented as a period within which the health problems occurred, and can be used as a starting point for more detailed research. Finally, the relationship between a number of health problems and disasters was limited to only one study or result and should not be considered indicative of a true relationship.

\section{References}

1. Center for Research on the Epidemiology of Disasters. The human cost of weatherrelated disasters: 1995-2015. Belgium/Switzerland; 2015.

2. Du W, FitzGerald GJ, Clark M, Hou XY. Health impacts of floods. Prehosp Disaster Med. 2010;25(3):265-272.

3. Alderman K, Turner LR, Tong S. Floods and human health: a systematic review. Environ Int. 2012;47:37-47.

4. Tempark T, Lueangarun S, Chatproedprai S, Wananukul S. Flood-related skin diseases: a literature review. Int J Dermatol. 2013;52(10):1168-1176.

5. Doocy S, Daniels A, Murray S, Kirsch TD. The human impact of floods: a historical review of events 1980-2009 and systematic literature review. PLoS Curr. 2013;5.

6. Doocy S, Dick A, Daniels A, Kirsch TD. The human impact of tropical cyclones: a historical review of events 1980-2009 and systematic literature review. PLoS Curr. 2013;5.

7. Goldman A, Eggen B, Golding B, Murray V. The health impacts of windstorms: a systematic literature review. Public Health. 2014;128(1):3-28.

8. Saulnier D, Brolin Ribacke K, von Schreeb J. No calm after the storm: a systematic review of human health following flood and storm disasters. PROSPERO: International Prospective Register of Systematic Reviews. 2016. https://www.crd. york.ac.uk/PROSPERO/.

9. Explanatory Notes: Guidelines. Center for Research on the Epidemiology of Disasters Web site. http://www.emdat.be/explanatory-notes. Accessed March 16, 2016.

10. Secretariat of the World Meteorological Organization. International meteorological vocabulary. QJ R Meteorol Soc. 1967;93(395):148.

11. World Health Organization. ICD-10: International Statistical Classification of Diseases and Related Health Problems. http://apps.who.int/classifications/icd10/ browse/2010/en. Published 2010. Accessed April 15, 2016.

12. World Health Organization. Recommended Surveillance Standards. Geneva, Switzerland: WHO; 1999.

13. Moher D, Liberati A, Tetzlaff J, Altman DG, Group TP. Preferred Reporting Items for Systematic Reviews and Meta-Analyses: the PRISMA statement. PLoS Med. 2009;6(7):e100097.

\section{Conclusion}

The review summarizes the current published knowledge on health effects of flood and storm disasters. It has shown an increase in some injuries, poisonings, infectious diseases, and chronic diseases or NCDs after floods and storms. However, there is a clear need for more information on the long-term changes in health, the strength of the relationships between floods or storms and health problems, and on changes in health after floods only. It has highlighted areas for consideration by responders, but stronger results are required before specific recommendations can be made.

Despite the difficulty of conducting research and collecting data in disaster settings, a move must be made towards more rigorous, systematic, and high-quality research. It is necessary to move on from descriptive studies if an improvement is expected in knowledge and outcomes. Decision making regarding type and quantity of medical responses should be done before a disaster occurs and should use the best available data that are based on research that is held to the same standards as research conducted outside disaster settings. Conducting high-quality, systematic research is one step towards improving the knowledge base and consequently, the quality and effectiveness of the medical response to storms and floods.

\section{Acknowledgements}

The authors would like to thank the librarians C. Gornitzki and L. Mathiesen at Karolinska Institutet University Library (Solna, Sweden) for their assistance in developing the search strategy, and F. von Schreeb for data extraction.

\section{Supplementary Material}

To view supplementary material for this article, please visit https:/doi.org/10.1017/S1049023X17006574

14. Ahmed Z, Khan AA, Nisar N. Frequency of infectious diseases among flood affected people at district Rajanpur, Pakistan. PakJ Med Sci. 2011;27(4):866-869.

15. Averhoff F, Young S, Mott J, et al. Morbidity surveillance after Hurricane Katrina Arkansas, Louisiana, Mississippi, and Texas, September 2005. MMWR. 2006; 55(26):727-731.

16. Centers for Disease Control and Prevention. Epidemiologic assessment of the impact of four hurricanes - Florida, 2004. MMWR. 2005;54(28):693-697.

17. Brewer RD, Morris PD, Cole TB. Hurricane-related emergency department visits in an inland area: an analysis of the public health impact of Hurricane Hugo in North Carolina. Ann Emerg Med. 1994;23(4):731-736.

18. Cariappa MP, Khanduri P. Health emergencies in large populations: the Orissa experience. Med J Armed Forces India. 2003;59(4):286-289.

19. Centers for Disease Control and Prevention. Hurricane Ike rapid needs assessment Houston, Texas, September 2008. MMWR. 2009;58(38):1066-1071.

20. Henderson AK, Lillibridge SR, Salinas C, Graves RW, Roth PB, Noji EK. Disaster medical assistance teams: providing health care to a community struck by Hurricane Iniki. Ann Emerg Med. 1994;23(4):726-730.

21. Howe E, Victor D, Price EG. Chief complaints, diagnoses, and medications prescribed seven weeks post-Katrina in New Orleans. Prehosp Disaster Med. 2008; 23(1):41-47.

22. Lee LE, Fonseca V, Brett KM, et al. Active morbidity surveillance after Hurricane Andrew - Florida, 1992. J Am Med Assoc. 1993;270(5):591-594.

23. Centers for Disease Control and Prevention. Rapid assessment of the needs and health status of older adults after Hurricane Charley Charlotte, DeSoto, and Hardee counties, Florida, August 27-31, 2004. MMWR. 2004;53(36):837-840.

24. Lopez C, Bergeron T, Ratard R, et al. Injury and illness surveillance in hospitals and acute care facilities after Hurricanes Katrina and Rita - New Orleans Area, Louisiana, September 25-October 15, 2005. MMWR. 2006;55(2):35-38.

25. McNabb SJ, Kelso KY, Wilson SA, McFarland L, Farley TA. Hurricane Andrewrelated injuries and illnesses, Louisiana, 1992. South Med J. 1995;88(6):615-618.

26. McNeil KM. Surveillance for illness and injury after Hurricane Katrina - New Orleans, Louisiana, September 8-25, 2005. MMWR. 2005;54(40):1018-1021. 
27. McNeill KM, Byers P, Kittle T, et al. Surveillance for illness and injury after Hurricane Katrina - three counties, Mississippi, September 5-October 11, 2005. MMWR. 2006;55(9):231-234.

28. Noe RS, Schnall AH, Wolkin AF, et al. Disaster-related injuries and illnesses treated by American Red Cross disaster health services during Hurricanes Gustav and Ike. South Med J. 2013;106(1):102-108.

29. Nufer KE, Wilson-Ramirez G. A comparison of patient needs following two hurricanes. Prehosp Disaster Med. 2004;19(2):146-149.

30. Nufer KE, Wilson-Ramirez G, Crandall CS. Different medical needs between hurricane and flood victims. Wilderness Environ Med. 2003;14(2):89-93.

31. Paul BK, Rahman MK, Rakshit BC. Post-Cyclone Sidr illness patterns in coastal Bangladesh: an empirical study. Nat Hazards. 2011;56(3):841-852.

32. Quinlisk P, Jones MJ, Bostick NA, et al. Results of rapid needs assessments in rural and urban Iowa following large-scale flooding events in 2008. Disaster Med Public Health Prep. 2011;5(4):287-292.

33. Wu J, Xiao J, Li T, et al. A cross-sectional survey on the health status and the health-related quality of life of the elderly after flood disaster in Bazhong City, Sichuan, China. BMC Public Health. 2015;15:163.

34. Williams EW, Williams-Johnson J, French S, Singh P, McDonald A, Ford R. The effect of Hurricane Ivan on emergency department operations at the University Hospital of the West Indies. West Indian Med J. 2005;54(4):232-235.

35. Vest JR, Valadez AM. Health conditions and risk factors of sheltered persons displaced by Hurricane Katrina. Prehosp Disaster Med. 2006;21(2):55-58.

36. Sullivent EE, West CA, Noe RS, Thomas KE, Wallace LJ, Leeb RT. Nonfatal injuries following Hurricane Katrina-New Orleans, Louisiana, 2005. J Safety Res. 2006;37(2):213-217.

37. Siddique AK, Baqui AH, Eusof A, Zaman K. 1988 floods in Bangladesh: pattern of illness and causes of death. J Diarrhoeal Dis Res. 1991;9(4):310-314.

38. Sharma AJ, Weiss EC, Young SL, et al. Chronic disease and related conditions at emergency treatment facilities in the New Orleans area after Hurricane Katrina. Disaster Med Public Health Prep. 2008;2(1):27-32.

39. Centers for Disease Control and Prevention. Morbidity surveillance following the Midwest flood - Missouri, 1993. MMWR. 1993;42(41):797-798.

40. Read DJ, Holian A, Moller CC, Poutawera V. Surgical workload of a foreign medical team after Typhoon Haiyan. ANZ J Surg. 2016;86(5):361-365.

41. Centers for Disease Control and Prevention. Preliminary report: medical examiner reports of deaths associated with Hurricane Andrew-Florida, August 1992. MMWR. 1992;41(35):641-644.

42. Jones KT, Grigg M, Crockett LK, et al. Preliminary medical examiner reports of mortality associated with Hurricane Charley - Florida, 2004. MMWR. 2004;53(36): 835-837.

43. Combs DL, Parrish RG, McNabb SJ, Davis JH. Deaths related to Hurricane Andrew in Florida and Louisiana, 1992. Int J Epidemiol. 1996;25(3):537-544.

44. Nelson S, Luten J, Jones K, et al. Mortality associated with Hurricane Katrina Florida and Alabama, August-October 2005. MMWR. 2006;55(9):239-342.

45. Ragan P, Schulte J, Alelson SJ, Jones KT. Mortality surveillance - 2004 to 2005 Florida hurricane-related deaths. Am J Forensic Med Pathol. 2008;29(2):148-153.

46. Zane DF, Bayleyegn TM, Hellsten J, et al. Tracking deaths related to Hurricane Ike, Texas, 2008. Disaster Med Public Health Prep. 2011;5(1):23-28.

47. Centers for Disease Control and Prevention. Medical examiner/coroner reports of deaths associated with Hurricane Hugo - South Carolina. MMWR. 1989;38(44): 754, 759-762.

48. Jani AA, Fierro M, Kiser S, et al. Hurricane Isabel-related mortality-Virginia, 2003. J Public Health Manag Pract. 2006;12(1):97-102.

49. Myung HN, Jang JY. Causes of death and demographic characteristics of victims of meteorological disasters in Korea from 1990 to 2008. Environ Health. 2011;10:82.

50. Hampson N, Dunn S, Bronstein A, et al. Carbon monoxide exposures after Hurricane Ike - Texas, September 2008. MMWR. 2009;58(31):845-849.

51. Hampson NB, Lai MW, McNeil M, et al. Carbon monoxide poisoning after Hurricane Katrina - Alabama, Louisiana, and Mississippi, August-September 2005. MMWR. 2005;54(39):996-998.

52. Sniffen JC, Cooper TW, Johnson D, et al. Carbon monoxide poisoning from hurricane-associated use of portable generators - Florida, 2004. MMWR. 2005;54(28): 697-700.

53. Tucker M, Eichold B, Lofgren JP, et al. Carbon monoxide poisonings after two major hurricanes - Alabama and Texas, August-October 2005. MMWR. 2006;55(9): 236-239.

54. Staes C, Orengo JC, Malilay J, Rullan J, Noji E. Deaths due to flash floods in Puerto Rico, January, 1992 - implications for prevention. Int J Epidemiol. 1994;23(5): 968-975.

55. World Health Organization. Leptospirosis, India. Report of the investigation of a post-cyclone outbreak in Orissa, November 1999. Wkly Epidemiol Rec. 2000;75(27): $217-224$
56. Atchison CG, Wintermeyer LA, Kelly JR. Public health consequences of a flood disaster-Iowa, 1993. MMWR. 1993;42(34):653-656.

57. Brackbill RM, Caramanica K, Maliniak M, et al. Nonfatal injuries one week after Hurricane Sandy-New York City metropolitan area, October 2012. MMWR. 2014;63(42):950-954.

58. Daley WR, Shireley L, Gilmore R. A flood-related outbreak of carbon monoxide poisoning - Grand Forks, North Dakota. J Emerg Med. 2001;21(3):249-253.

59. Fife CE, Smith LA, Maus EA, et al. Dying to play video games: carbon monoxide poisoning from electrical generators used after hurricane Ike. Pediatrics. 2009;123(6): e1035-e1038.

60. Gagnon EB, Aboutanos MB, Malhotra AK, Dompkowski D, Duane TM, Ivatury RR. In the wake of Hurricane Isabel: a prospective study of post-event trauma and injury control strategies. Am Surg. 2005;71(3):194-197.

61. George McDowell N, Landron F, Glenn J, et al. Deaths associated with Hurricanes Marilyn and Opal - United States, September October 1995. MMWR. 1996; 45(29):32-38

62. Greenough PG, Lappi MD, Hsu EB, et al. Burden of disease and health status among Hurricane Katrina-displaced persons in shelters: a population-based cluster sample. Ann Emerg Med. 2008;51(4):426-432.

63. Kirsch TD, Wadhwani C, Sauer L, Doocy S, Catlett C. Impact of the 2010 Pakistan floods on rural and urban populations at six months. PLoS Curr. 2012;4: e4fdfb212d2432.

64. Kunii O, Nakamura S, Abdur R, Wakai S. The impact on health and risk factors of the diarrhea epidemics in the 1998 Bangladesh floods. Public Health. 2002; 116(2):68-74

65. Morrow J, Norman E, Dickens R, et al. Rapid community health and needs assessments after Hurricanes Isabel and Charley - North Carolina, 2003-2004. MMWR. 2004;53(36):840-842.

66. Ridenour ML, Cummings KJ, Sinclair JR, Bixler D. Displacement of the underserved: medical needs of Hurricane Katrina evacuees in West Virginia. J Health Care Poor Underserved. 2007;18(2):369-381.

67. Hendrickson LA, Vogt RL, Goebert D, Pon E. Morbidity on Kauai before and after Hurricane Iniki. Prev Med. 1997;26(5 Pt 1):711-716.

68. Miller JA, Kearney GD, Proescholdbell SK. Surveillance of injuries in Eastern North Carolina following Hurricane Irene using emergency department data. N C Med J. 2013;74(4):272-278.

69. Platz E, Cooper HP, Silvestri S, Siebert CF. The impact of a series of hurricanes on the visits to two central Florida emergency departments. J Emerg Med. 2007;33(1): 39-46.

70. Chen BC, Shawn LK, Connors NJ, et al. Carbon monoxide exposures in New York City following Hurricane Sandy in 2012. Clin Toxicol (Phila). 2013;51(9): 879-885.

71. Kim HK, Takematsu M, Biary R, Williams N, Hoffman RS, Smith SW. Epidemic gasoline exposures following Hurricane Sandy. Prehosp Disaster Med. 2013;28(6): 586-591.

72. Forrester MB. Impact of Hurricane Ike on Texas poison center calls. Disaster Med Public Health Prep. 2009;3(3):151-157.

73. Forrester MB. Impact of Hurricane Rita on Texas poison center calls. Prehosp Disaster Med. 2008;23(3):256-262.

74. Quinn B, Baker R, Pratt J. Hurricane Andrew and a pediatric emergency department. Ann Emerg Med. 1994;23(4):737-741.

75. Alhinai MY. Tropical Cyclone Gonu: number of patients and pattern of illnesses in the primary health centers in A'seeb area, Muscat, Sultanate of Oman. Oman Med J. 2011;26(4):223-228.

76. Centers for Disease Control and Prevention. Hurricanes and hospital emergency room visits -Mississippi, Rhode Island, Connecticut. MMWR. 1986;34(51-52): 765-770.

77. Sjoberg L, Yearwood R. Impact of a Category 3 hurricane on the need for surgical hospital care. Prehosp Disaster Med. 2007;22(3):194-198.

78. Sheppa CM, Stevens J, Philbrick JT, Canada M. The effect of a Class IV hurricane on emergency department operations. Am J Emerg Med. 1993;11(5):464-467.

79. Centers for Disease Control and Prevention. Morbidity and mortality associated with Hurricane Floyd-North Carolina, September-October 1999. MMWR. 2000;49(17): 369-372.

80. Longmire AW, Burch J, Broom LA. Morbidity of Hurricane Elena. South Med J. 1988;81(11):1343-1346.

81. Warner GS. Increased incidence of domestic animal bites following a disaster due to natural hazards. Prehosp Disaster Med. 2010;25(2):188-190.

82. Waring SC, DesVignes-Kendrick M, Arafat RR, et al. Tropical Storm Allison rapid needs assessment - Houston, Texas, June 2001. J Am Med Assoc. 2002; 287(20):2646-2647.

83. Deng Z, Xun H, Zhou M, et al. Impacts of tropical cyclones and accompanying precipitation on infectious diarrhea in cyclone landing areas of Zhejiang Province, China. Int J Environ Res Public Health. 2015;12(2):1054-1068. 
84. Panda S, Pati KK, Bhattacharya MK, Koley H, Pahari S, Nair GB. Rapid situation and response assessment of diarrhea outbreak in a coastal district following tropical cyclone Aila in India. Indian J Med Res. 2011;133:395-400.

85. Myint NW, Kaewkungwal J, Singhasivanon P, et al. Are there any changes in burden and management of communicable diseases in areas affected by Cyclone Nargis? Confl Health. 2011;5(1):9.

86. Setzer C, Domino ME. Medicaid outpatient utilization for waterborne pathogenic illness following Hurricane Floyd. Public Health Rep. 2004;119(5):472-478.

87. Vilain P, Pages F, Combes X, et al. Health impact assessment of Cyclone Bejisa in Reunion Island (France) using syndromic surveillance. Prehosp Disaster Med. 2015; 30(2):137-144.

88. Greene SK, Wilson EL, Konty KJ, Fine AD. Assessment of reportable disease incidence after Hurricane Sandy, New York City, 2012. Disaster Med Public Health Prep. 2013;7(5):513-521.

89. Fredrick T, Ponnaiah M, Murhekar MV, et al. Cholera outbreak linked with lack of safe water supply following a tropical cyclone in Pondicherry, India, 2012. J Health Popul Nutr. 2015;33(1):31-38.

90. Palacio H, Shah U, Kilborn C, et al. Norovirus outbreak among evacuees from Hurricane Katrina - Houston, Texas, September 2005. MMWR. 2005;54(40): 1016-1018.

91. Bhattacharjee S, Bhattacharjee S, Bal B, Pal R, Niyogi SK, Sarkar K. Is Vibrio fluvialis emerging as a pathogen with epidemic potential in coastal region of eastern India following cyclone Aila? J Health Popul Nutr. 2010;28(4):311-317.

92. Bhunia R, Ghosh S. Waterborne cholera outbreak following Cyclone Aila in Sundarban area of West Bengal, India, 2009. Trans R Soc Trop Med Hyg. 2011; 105(4):214-219.

93. Trevejo RT, Rigau-Perez JG, Ashford DA, et al. Epidemic leptospirosis associated with pulmonary hemorrhage-Nicaragua, 1995. J Infect Dis. 1998;178(5):1457-1463.

94. Sanders EJ, Rigau-Perez JG, Smits HL, et al. Increase of leptospirosis in denguenegative patients after a hurricane in Puerto Rico in 1996. Am J Trop Med Hyg. 1999;61(3):399-404

95. Lin PC, Lin HJ, Guo HR, Chen KT. Epidemiological characteristics of lower extremity cellulitis after a typhoon flood. PLoS ONE. 2013;8(6):e65655.

96. Engelthaler D, Lewis K, Anderson S, et al. Vibrio illnesses after Hurricane Katrinamultiple states, August-September 2005. MMWR. 2005;54(37):928-931.

97. Caillouet KA, Michaels SR, Xiong X, Foppa I, Wesson DM. Increase in West Nile neuroinvasive disease after Hurricane Katrina. Emerg Infect Dis. 2008;14(5):804-807.

98. Beatty ME, Hunsperger E, Long E, et al. Mosquito-borne infections after Hurricane Jeanne, Haiti, 2004. Emerg Infect Dis. 2007;13(2):308-310.

99. Schwartz BS, Harris JB, Khan AI, et al. Diarrheal epidemics in Dhaka, Bangladesh, during three consecutive floods: 1988, 1998, and 2004. Am J Trop Med Hyg. 2006; 74(6):1067-1073

100. Gertler M, Durr M, Renner P, et al. Outbreak of Cryptosporidium hominis following river flooding in the city of Halle (Saale), Germany, August 2013. BMC Infect Dis. 2015;15:88.

101. Centers for Disease Control and Prevention. Early warning disease surveillance after a flood emergency-Pakistan, 2010. MMWR. 2012;61(49):1002-1007.

102. Milojevic A, Armstrong B, Hashizume M, et al. Health effects of flooding in rural Bangladesh. Epidemiology. 2012;23(1):107-115.

103. Smith JK, Young MM, Wilson KL, Craig SB. Leptospirosis following a major flood in Central Queensland, Australia. Epidemiol Infect. 2013;141(3):585-590.

104. Dechet AM, Parsons M, Rambaran M, et al. Leptospirosis outbreak following severe flooding: a rapid assessment and mass prophylaxis campaign; Guyana, JanuaryFebruary 2005. PLOS ONE. 2012;7(7):e39672.

105. Pradutkanchana J, Pradutkanchana S, Kemapanmanus M, Wuthipum N, Silpapojakul K. The etiology of acute pyrexia of unknown origin in children after a flood. Southeast Asian J Trop Med Public Health. 2003;34(1):175-178.

106. Bich TH, Quang LN, Ha le TT, Hanh TT, Guha-Sapir D. Impacts of flood on health: epidemiologic evidence from Hanoi, Vietnam. Glob Health Action. 2011;4:6356.

107. McCarthy MC, Haberberger RL, Salib AW, et al. Evaluation of arthropod-borne viruses and other infectious disease pathogens as the causes of febrile illnesses in the Khartoum Province of Sudan. J Med Virol. 1996;48(2):141-146.
108. Cookson ST, Soetebier K, Murray EL, et al. Internet-based morbidity and mortality surveillance among Hurricane Katrina evacuees in Georgia. Prev Chronic Dis. 2008; 5(4):A133.

109. Swerdel JN, Janevic TM, Cosgrove NM, Kostis JB, Myocardial Infarction Data Acquisition System Study G. The effect of Hurricane Sandy on cardiovascular events in New Jersey. J Am Heart Assoc. 2014;3(6):e001354.

110. Gautam S, Menachem J, Srivastav SK, Delafontaine P, Irimpen A. Effect of Hurricane Katrina on the incidence of acute coronary syndrome at a primary angioplasty center in New Orleans. Disaster Med Public Health Prep. 2009;3(3): 144-150.

111. Fonseca VA, Smith H, Kuhadiya N, et al. Impact of a natural disaster on diabetes: exacerbation of disparities and long-term consequences. Diabetes Care. 2009; 32(9):1632-1638.

112. Park KJ, Moon JY, Ha JS, et al. Impacts of heavy rain and typhoon on allergic disease. Osong Public Health Res Perspect. 2013;4(3):140-145.

113. Rath B, Donato J, Duggan A, et al. Adverse health outcomes after Hurricane Katrina among children and adolescents with chronic conditions. J Health Care Poor Underserved. 2007;18(2):405-417.

114. Rabito F, Perry S, Davis W, Levetin E. The relationship between mold exposure and allergic response in post-Katrina New Orleans. Am J Respir Crit Care Med. 2010;181(1).

115. Simeon DT, Grantham-McGregor SM, Walker SP, Powell CA. Effects of a hurricane on growth and morbidity in children from low-income families in Kingston, Jamaica. Trans R Soc Trop Med Hyg. 1993;87(5):526-528.

116. Barrios RE, Stansbury JP, Palencia R, Medina MT. Nutritional status of children under 5 years of age in three hurricane-affected areas of Honduras. Rev Panam Salud Publica. 2000;8(6):380-384.

117. Howard D, Zhang R, Huang Y, Kutner N. Hospitalization rates among dialysis patients during Hurricane Katrina. Prehosp Disaster Med. 2012;27(4):325-329.

118. Duff EM, Cooper ES. Neural tube defects in Jamaica following Hurricane Gilbert. Am J Public Health. 1994;84(3):473-476.

119. Ng JM, Thorpe J, Walton C, Atkin SL, Kilpatrick ES. The effect of extensive flooding in Hull on the glycemic control of diabetes patients. Diabet Med. 2010; 27(2):108.

120. Rodriguez-Llanes JM, Ranjan-Dash S, Degomme O, Mukhopadhyay A, GuhaSapir D. Child malnutrition and recurrent flooding in rural eastern India: a community-based survey. BMJ Open. 2011;1(2):e000109.

121. Sihawong R, Janwantanakul P, Pensri P. Incidence of and risk factors for musculoskeletal symptoms in the neck and low-back during severe flooding in Bangkok in 2011. J Rehabil Med. 2012;44(8):624-628.

122. Cummings KJ, Cox-Ganser J, Riggs MA, Edwards N, Hobbs GR, Kreiss K. Health effects of exposure to water-damaged New Orleans homes six months after Hurricanes Katrina and Rita. Am J Public Health. 2008;98(5):869-875.

123. Rabito FA, Iqbal S, Kiernan MP, Holt E, Chew GL. Children's respiratory health and mold levels in New Orleans after Katrina: a preliminary look. J Allergy Clin Immunol. 2008;121(3):622-625.

124. Hendrickson LA, Vogt RL. Mortality of Kauai residents in the 12-month period following Hurricane Iniki. Am J Epidemiol. 1996;144(2):188-191.

125. McKinney N, Houser C, Meyer-Arendt K. Direct and indirect mortality in Florida during the 2004 hurricane season. Int J Biometeorol. 2011;55(4):533-546.

126. Kutner NG, Muntner P, Huang Y, et al. Effect of Hurricane Katrina on the mortality of dialysis patients. Kidney Int. 2009;76(7):760-766.

127. Ahern M, Kovats RS, Wilkinson P, Few R, Matthies F. Global health impacts of floods: epidemiologic evidence. Epidemiol Rev. 2005;27:36-46.

128. Watson JT, Gayer M, Connolly MA. Epidemics after natural disasters. Emerg Infect Dis. 2007;13(1):1-5.

129. Alson R, Alexander D, Leonard RB, Stringer LW. Analysis of medical treatment at a field hospital following Hurricane Andrew, 1992. Ann Emerg Med. 1993; 22(11):1721-1728.

130. Jhung MA, Shehab N, Rohr-Allegrini C, et al. Chronic disease and disasters medication demands of Hurricane Katrina evacuees. Am J Prev Med. 2007;33(3): 207-210. 